\title{
A pre-genetic study of the isoforms of malic enzyme associated with lipid accumulation in Mucor circinelloides
}

\author{
Yuanda Song, James P. Wynn, Yonghua Li, David Grantham \\ and Colin Ratledge
}

Centre for Advanced Lipid Research, Department of Biological Sciences, University of Hull, Hull HU6 7RX, UK
Author for correspondence: James P. Wynn. Tel: +44 1482 465507. Fax: +44 1482465458. e-mail: j.p.wynn@biosci.hull.ac.uk

The oleaginous fungus Mucor circinelloides possesses at least six isoforms of malic enzyme (EC 1.1.1.40), a key lipogenic enzyme in filamentous fungi. These isoforms were detected using a specific stain for activity after native PAGE of cell extracts. Only one isoform (isoform IV) was associated with lipid accumulation, appearing only after $\mathbf{N}$-exhaustion from the medium (which is a pre-requisite for lipid accumulation) in glucose-growing cells. Isoforms I, II, V and VI were involved in anaerobic growth and only appeared under $\mathrm{O}_{2}$-limited conditions. Isoform III appeared to be constitutive and was formed under conditions of active (balanced) growth and is therefore thought to play a crucial role in basic metabolism. Growth on acetate increased the amount of cell lipid (from $25-27 \%$ in glucose-grown cells to $37-38 \%$ in acetate-grown cells) accumulated by $M$. circinelloides and this was associated with the appearance of isoform IV of malic enzyme prior to $\mathrm{N}$-exhaustion in these cultures. Amino acid sequence analysis of isoforms III and IV suggests that these two malic enzymes may be encoded by a single gene and that isoform IV is formed from isoform III by post-translational modification initiated by either $\mathbf{N}$-limitation (when glucose was the carbon source) or growth on acetate as the sole carbon source.

Keywords: isoforms, continuous culture, filamentous fungi

\section{INTRODUCTION}

Malic enzyme (EC 1.1.1.38, 1.1.1.39 and 1.1.1.40) catalyses the reaction: L-malate $+\mathrm{NAD}(\mathrm{P})^{+} \leftrightarrow$ pyruvate $+\mathrm{CO}_{2}+\mathrm{NAD}(\mathrm{P}) \mathrm{H}$. Although malic enzyme activity was first reported over 50 years ago (Ochoa et al., 1947) and has since been studied in animals, plants and both eukaryotic and prokaryotic micro-organisms, the cellular function of this enzyme remains equivocal. The apparent universal possession of malic enzyme and the similarity, at the amino acid and DNA level, of malic enzymes from disparate sources (Hodnett et al., 1996; Viljoen et al., 1994; Walter et al., 1994) suggest a fundamental and crucial cellular function for this enzyme. Amongst the suggested functions for malic enzyme are roles in the metabolism of acetate (McCullough \& Roberts, 1974), involvement in anaerobic growth (Boles et al., 1998), and generation of NADPH for lipid biosynthesis (Evans \& Ratledge, 1985; Frenkel, 1975; Hodnett et al., 1996). Recent work in this laboratory has focused on the apparently crucial role malic enzyme plays in lipid metabolism in filamentous fungi (Wynn \& Ratledge, 1997, 2000; Wynn et al., 1997, 1999), where it is considered to specifically provide the reductive reactions in fatty acid synthase with NADPH (Ratledge \& Wynn, 2000).

Despite strong evidence that malic enzyme activity is a key factor in ensuring maximal lipid accumulation in filamentous fungi, the link between malic enzyme activity and lipid accumulation is uncertain. Fungi possessing a high activity of malic enzyme do not necessarily accumulate lipid (Wynn et al., 1999; J. P. Wynn, unpublished work). This finding, together with the presence of multiple isoforms of malic enzyme in some fungi (Savitha et al., 1997; Zink, 1972; J. P. Wynn, unpublished work), has led us to consider the possibility that several forms of malic enzyme may exist in Mucor circinelloides, perhaps even encoded by different genes. Specific isoforms of malic enzyme may, therefore, be associated with lipid accumulation whilst others have other cellular functions. As our ultimate aim is to clone 
the gene for malic enzyme, to overexpress it and so potentially boost lipid accumulation in filamentous fungi (and perhaps also in oilseed plants), it is crucial that we have a clear understanding of the number and cellular functions of the discrete malic enzyme isoforms in eukaryotic cells.

The aim of this study was to assess the impact of a range of growth conditions known to affect malic enzyme activity in micro-organisms and to determine their effect on (i) the total malic enzyme activity, (ii) the appearance of different isoforms of malic enzyme and (iii) lipid accumulation. In so doing we hoped to identify the isoform(s) of malic enzyme specifically associated with lipid accumulation in M. circinelloides.

\section{METHODS}

Chemicals. Unless otherwise stated all fine chemicals were obtained from Sigma.

Cultivation of fungi. Mucor circinelloides CBS 108.16 was grown in modified Kendrick media (Kendrick \& Ratledge, 1992). Medium for batch culture contained $50 \mathrm{~g}$ glucose $1^{-1}$ and $2 \mathrm{~g}$ ammonium tartrate $\mathrm{l}^{-1}$; N-limited medium for

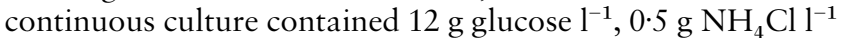
and $0 \cdot 1 \mathrm{~g}$ yeast extract $\mathrm{l}^{-1}$. Cultures were grown in either $1 \mathrm{l}$ stirred bottles as previously described (Wynn et al., 1997) or in $5 \mathrm{l}$ fermenters with $4 \mathrm{l}$ medium. Aeration was at $1.51 \mathrm{air} \mathrm{min}^{-1}$ and $\mathrm{pH}$ was controlled at $5 \cdot 5-6 \cdot 5$ by automatic addition of $2 \mathrm{M} \mathrm{KOH}$ and $2 \mathrm{M} \mathrm{H}_{2} \mathrm{SO}_{4}$, for glucose-grown cultures, or $50 \%(\mathrm{w} / \mathrm{w})$ acetic acid for acetic-acid-grown cultures in a $\mathrm{pH}$ auxostat, with an initial concentration of sodium acetate of $10 \mathrm{~g} \mathrm{l}^{-1}$ (Du Preez et al., 1997).

Continuous cultivation was in a 51 stirred chemostat with a working volume of 41 , aeration at $1.71 \mathrm{~min}^{-1}$ and stirring at $700 \mathrm{rev} \mathrm{min}^{-1}$. The $\mathrm{pH}$ was maintained between $5 \cdot 5$ and $6 \cdot 5$ and the dilution rate was adjusted by controlling the rate of medium addition. Wall growth was prevented by the absence of baffles and by reversing the direction of stirring every $60 \mathrm{~s}$. Anaerobic growth was achieved by bubbling $\mathrm{N}_{2}$ or $\mathrm{CO}_{2}$ through the air inlet. The dissolved $\mathrm{O}_{2}$ tension was measured using a galvanic $\mathrm{O}_{2}$ electrode calibrated to $100 \%$ of fullscale deflection immediately prior to inoculation with the chemostat being flushed with air at $1.71 \mathrm{~min}^{-1}$. Volume control of the fermenter was achieved by a level sensor opening and closing a solenoid valve allowing excess culture to flow directly to the waste bottle.

All cultivations were carried out at $30{ }^{\circ} \mathrm{C}$.

Determination of cell dry weight. Biomass was harvested by filtration through a preweighed dried filter (Whatman GF/A), washed twice with distilled water and dried at $110^{\circ} \mathrm{C}$ to a constant weight.

Determination of ammonium, glucose and acetate. The ammonium concentration in the culture medium was measured using the indophenol method of Chaney \& Marbach (1962). The glucose concentration in the culture was determined using a glucose oxidase Perid-test kit (Boehringer Mannheim) according to the manufacturer's instructions.

The acetate concentration in the culture was determined by GC using an ATI Unicam 610 series gas chromatograph fitted with a flame-ionization detector and a BPX 70 capillary column packed with $10 \%(\mathrm{w} / \mathrm{w})$ diethylene glycol succinate on Chromosorb W-AW. The oven temperature of $120^{\circ} \mathrm{C}$ was increased at a rate of $6^{\circ} \mathrm{C} \min ^{-1}$ to $165^{\circ} \mathrm{C}$. The inlet and detector temperatures were $135^{\circ} \mathrm{C}$ and $250^{\circ} \mathrm{C}$, respectively. The carrier gas was helium at $5 \mathrm{ml} \mathrm{min}{ }^{-1}$. Acetate peaks were identified and quantified by reference to an acetate standard.

Preparation of cell extracts. Biomass was harvested by filtration under reduced pressure through a Whatman filter and washed three times with distilled water. Harvested cells were suspended in extraction buffer $\left[100 \mathrm{mM} \mathrm{KH}_{2} \mathrm{PO}_{4} /\right.$ $\mathrm{KOH}$, pH 7.5 , containing $20 \%$ (w/v) glycerol, $1 \mathrm{mM}$ benzamidine. $\mathrm{HCl}$ and $1 \mathrm{mM} \mathrm{DTT}]$ and disrupted by passage once through a One Shot Cell Disrupter (Constant Systems) at $64 \mathrm{MPa}$. The disrupted cell suspensions were centrifuged at $10000 \mathrm{~g}$ for $10 \mathrm{~min}$ at $4{ }^{\circ} \mathrm{C}$ and the supernatants were used for enzyme analysis. Protein concentrations were determined using the method of Bradford (1976) with BSA as a standard.

Detection of malic enzyme activity and malic enzyme isoforms. The activity of malic enzyme was assayed according to the method of Hsu \& Lardy (1969) with malate at $25 \mathrm{mM}$.

Malic enzyme isoforms were distinguished by activity staining of native-PAGE. Native-PAGE was prepared according to Hames (1985) using 10\% (w/v) acrylamide with the omission of SDS. Activity staining of malic enzyme on native gels was carried out according to the method of Chang et al. (1991).

Analysis of cell lipid. Biomass was harvested by filtration, rapidly frozen, then freeze-dried. Cell lipid was extracted with chloroform/methanol $(2: 1, \mathrm{v} / \mathrm{v})$ (Folch et al., 1957) and determined gravimetrically. The fatty acid profile of the cell lipid was analysed as previously described (Wynn \& Ratledge, 2000).

\section{Purification of malic enzyme isoforms III and IV}

Step one. A crude enzyme extract was centrifuged at $100000 \mathrm{~g}$ for $60 \mathrm{~min}$ at $4^{\circ} \mathrm{C}$ and the supernatant was carried forward to step two.

Step two. The protein precipitated at an ammonium sulphate concentration between 50 and $60 \%$ saturation was collected by centrifugation at $16000 \mathrm{~g}$ at $4{ }^{\circ} \mathrm{C}$ and resuspended in a minimum volume of extraction buffer.

Step three. The resuspended protein from step two was loaded onto a Sephacryl S-200-HR gel filtration column $(95 \mathrm{~cm} \times 2.5 \mathrm{~cm})$ and eluted with $10 \mathrm{mM}$ Tris $/ \mathrm{HCl}$ buffer, $\mathrm{pH} 7 \cdot 4$, containing $20 \%(\mathrm{w} / \mathrm{v})$ glycerol, $1 \mathrm{mM}$ DTT and $1 \mathrm{mM}$ benzamidine. $\mathrm{HCl}$. Fractions of $3 \mathrm{ml}$ were collected and the most enzymically active were retained and pooled.

Step four. The pooled active fractions from step three were applied to a DEAE anion-exchange column $(16 \mathrm{~cm} \times 2 \mathrm{~cm})$ and proteins were eluted with the Tris $/ \mathrm{HCl}$ buffer used in step 3 containing a magnesium diacetate gradient between $25 \mathrm{mM}$ and $45 \mathrm{mM}(300 \mathrm{ml})$. Again, $3 \mathrm{ml}$ fractions were collected and the active fractions were pooled. The volume of the active fractions was reduced to approximately $2 \mathrm{ml}$ by ultrafiltration through an Amicon PM 30 membrane filter.

Step five. The concentrated sample from step four was applied to a Sephacryl S-200-HR gel filtration column $(95 \mathrm{~cm} \times 2.5 \mathrm{~cm})$ and eluted with $10 \mathrm{mM}$ Tris $/ \mathrm{HCl}$ buffer, pH 6.0 , containing $20 \%(\mathrm{w} / \mathrm{v})$ glycerol, $1 \mathrm{mM}$ DTT and $1 \mathrm{mM}$ benzamidine. $\mathrm{HCl}$. Active fractions were collected and pooled.

Step six. The active fraction was applied to a Mimetic Green column (Affinity Chromatography) $(20 \mathrm{~cm} \times 1.5 \mathrm{~cm})$ and the protein was eluted with the Tris/ $\mathrm{HCl}$ buffer used in step 5 , containing a magnesium diacetate gradient between 0 and $150 \mathrm{mM}(350 \mathrm{ml})$. The most active fraction was retained and 


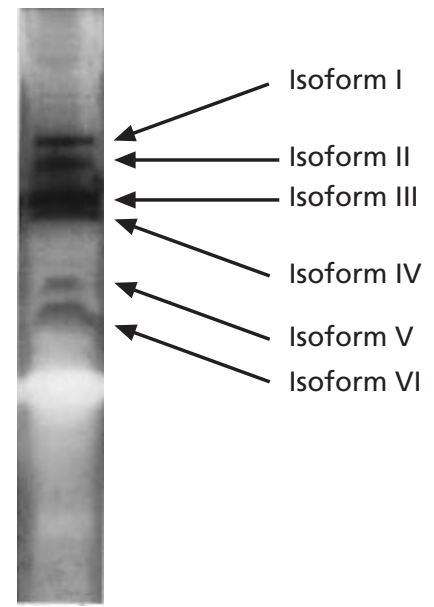

Fig. 1. Isoforms of malic enzyme (EC 1.1.1.40) in $M$ circinelloides. The isoforms were separated by native PAGE then visualized using an activity stain (Chang et al., 1991).

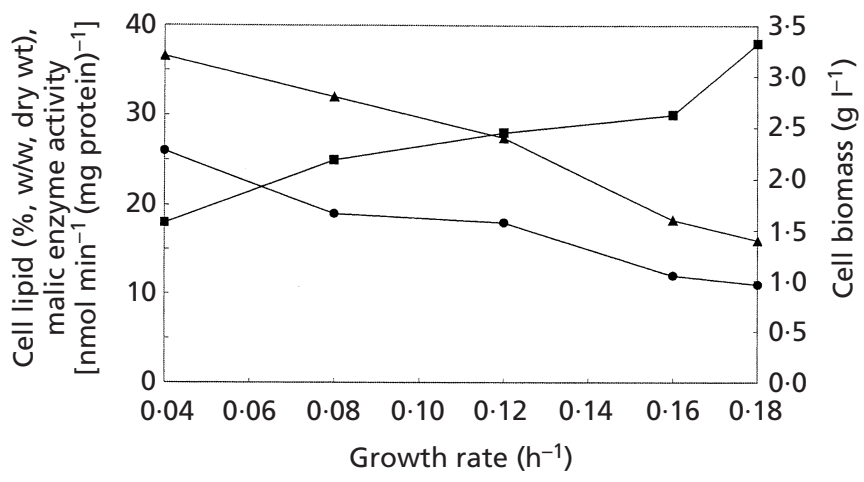

Fig. 2. Effect of growth rate on malic enzyme activity and lipid content of $M$. circinelloides. $M$. circinelloides was cultivated in a 4 I chemostat in N-limiting medium. $\boldsymbol{\Delta}$, Cell dry weight; $\mathbf{\square}$, malic enzyme activity; and $\boldsymbol{O}$, cell lipid content.

assessed for purity by SDS-PAGE, staining with Coomassie blue (Hames, 1985).

\section{RESULTS AND DISCUSSION}

\section{Identification of isoforms of malic enzyme in M. circinelloides}

When M. circinelloides was cultivated in stirred 11 bottles, the biomass contained at least six isoforms of $\mathrm{NADP}^{+}$-dependent malic enzyme (i.e. EC 1.1.1.40), distinguished by activity staining of an extract separated using native PAGE (see Fig. 1). No $\mathrm{NAD}^{+}$-dependent malic enzyme activity was detected in $M$. circinelloides. The visualized bands were confirmed as being malic enzyme and not an endogenous activity of some other dehydrogenase or malate dehydrogenase as no bands were visible when malate was omitted from the reaction mixture and, in a separate spectrophotometric assay of

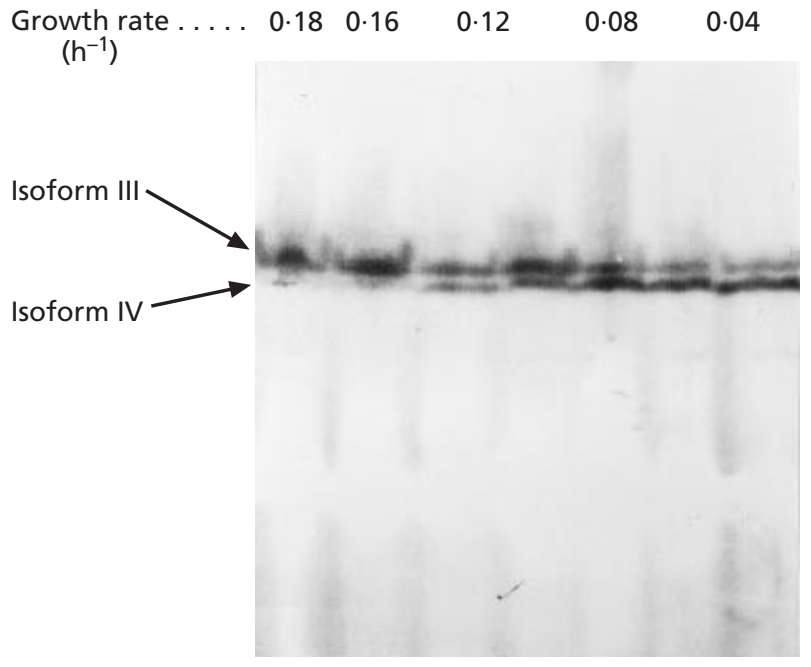

Fig. 3. Effect of growth rate on isoforms of malic enzyme (EC 1.1.1.40) in $M$. circinelloides. Fungal biomass was cultivated in a chemostat on $\mathrm{N}$-limiting medium at various growth rates. Extracts were prepared from steady-state cultures and stained for malic enzyme activity after native PAGE.

cell-free extracts, malate dehydrogenase activity with $\mathrm{NADPH}$ and oxaloacetate was not detected (data not shown).

With regard to the number of isoforms of malic enzyme that $M$. circinelloides possesses, this fungus appears to be the most prolific organism studied to date. Although more than one isoform of this enzyme has previously been reported in other fungi (Savitha et al., 1997; Zink, 1972; J. P. Wynn, unpublished work), none has yielded more than two isoforms and certainly not the six that we have detected during the present study.

\section{Effect of growth rate on malic enzyme activity and lipid accumulation in $\mathbf{M}$. circinelloides}

Previous work demonstrated that lipid accumulation in both M. circinelloides and Mortierella alpina (a related zygomycete fungus) occurred after $\mathrm{N}$-exhaustion in batch cultures during a period when malic enzyme activity began to decrease (Wynn et al., 1999). However, once malic enzyme activity became undetectable, lipid accumulation in both fungi ceased. It was hypothesized that the gene encoding malic enzyme was repressed after $\mathrm{N}$-exhaustion and that the period of lipogenesis after $\mathrm{N}$ exhaustion, and therefore the final extent of lipid accumulation, was probably a result of the resistance (or susceptibility) of the malic enzyme protein to degradation.

To investigate this phenomenon in more detail, $M$. circinelloides was cultivated in continuous culture at a range of growth rates (nitrogen being the limiting culture component) to reproduce the various stages of growth in batch culture. As the specific growth rate decreased, the amount of lipid in the biomass increased from $<15 \%$ 
Table 1. Effect of aerobic and anaerobic cultivation on growth and malic enzyme in M. circinelloides

\begin{tabular}{|c|c|c|c|c|}
\hline & \multicolumn{4}{|c|}{ Gas fed into fermenter } \\
\hline & Air & $\mathrm{O}_{2}$ & $\mathrm{CO}_{2}$ & $\mathbf{N}_{2}$ \\
\hline Cell dry weight $\left(\mathrm{g} \mathrm{l}^{-1}\right)$ & $6 \cdot 8$ & $6 \cdot 0$ & $3 \cdot 7$ & $5 \cdot 5$ \\
\hline Cell lipid $\left(\mathrm{g} \mathrm{l}^{-1}\right)$ & 7 & 13 & $1 \cdot 2$ & $1 \cdot 5$ \\
\hline $\begin{array}{l}\text { Malic enzyme activity }\left[\mathrm{nmol} \mathrm{min}^{-1}\right. \\
\left.(\mathrm{mg} \text { protein })^{-1}\right]\end{array}$ & 39 & 22 & 169 & 98 \\
\hline \multicolumn{5}{|c|}{ Presence or absence of isoform in biomass } \\
\hline I & - & - & + & + \\
\hline II & - & - & - & + \\
\hline III & + & + & + & + \\
\hline IV & + & + & - & - \\
\hline $\mathrm{V}$ & $+*$ & $+*$ & + & + \\
\hline VI & - & - & + & - \\
\hline
\end{tabular}

*In these cultures, the presence of isoform $\mathrm{V}$ was inconsistent and transitory. Its presence is thought to be an artefact, a result of contamination of the culture with $\mathrm{O}_{2}$-limited biomass associated with wall growth.

Table 2. Fatty acid profile of cell lipid in M. circinelloides grown under aerobic and anaerobic conditions

Values are relative $\%(\mathrm{w} / \mathrm{w})$ total fatty acids. $\mathrm{TR},<1 \%$.

\begin{tabular}{|lrcrr|}
\hline \multirow{2}{*}{ Fatty acid } & \multicolumn{4}{c|}{ Gas fed into fermenter } \\
\cline { 2 - 5 } & Air & $\mathrm{O}_{2}$ & $\mathrm{CO}_{2}$ & $\mathrm{~N}_{2}$ \\
\hline $12: 0$ & 2 & $\mathrm{TR}$ & 15 & 14 \\
$14: 0$ & 4 & 1 & 17 & 17 \\
$16: 0$ & 15 & 17 & 17 & 18 \\
$16: 1$ & 4 & 1 & 6 & 5 \\
$18: 0$ & 15 & 6 & $8 \cdot 2$ & 10 \\
$18: 1$ & 20 & 30 & 18 & 15 \\
$18: 2$ & 14 & 15 & 10 & 8 \\
$\gamma-18: 3$ & 18 & 25 & 6 & 7 \\
\hline
\end{tabular}

(w/w) dry weight at $0 \cdot 18 \mathrm{~h}^{-1}$ to $>25 \%(\mathrm{w} / \mathrm{w})$ dry weight at $0.04 \mathrm{~h}^{-1}$ (see Fig. 2). However, the activity of malic enzyme decreased at the lower growth rates, showing an inverse relationship to the cell lipid content. As maximum lipid accumulation was not necessarily associated with maximum malic enzyme activity, it appeared likely that malic enzyme must also be fulfilling cellular functions other than generating NADPH specifically for lipid accumulation.

\section{Detection of malic enzyme isoforms in continuous culture}

When cells were grown in continuous culture and analysed to determine the isoforms of malic enzyme present, a clear trend emerged. Under aerobic conditions, to ensure maximal lipid accumulation, only two isoforms of malic enzyme were consistently observed (III and IV, see Fig. 3). Isoform V was detected under aerobic conditions but the appearance of this isoform was transitory and was possibly an artefact caused by some cells being associated with 'wall growth' and which were therefore at least partially $\mathrm{O}_{2}$-limited before dropping back into the culture vessel. It is not thought that isoform $\mathrm{V}$ is directly involved in aerobic growth of $M$. circinelloides. At high growth rates $\left(0 \cdot 16-0 \cdot 18 \mathrm{~h}^{-1}\right)$, when the lipid content of the cells was low (approx. 10\%, w/w, dry wt), isoform III was the major malic enzyme activity present. At low growth rates $\left(0.08-0.04 \mathrm{~h}^{-1}\right)$, the lipid content of the cells was 

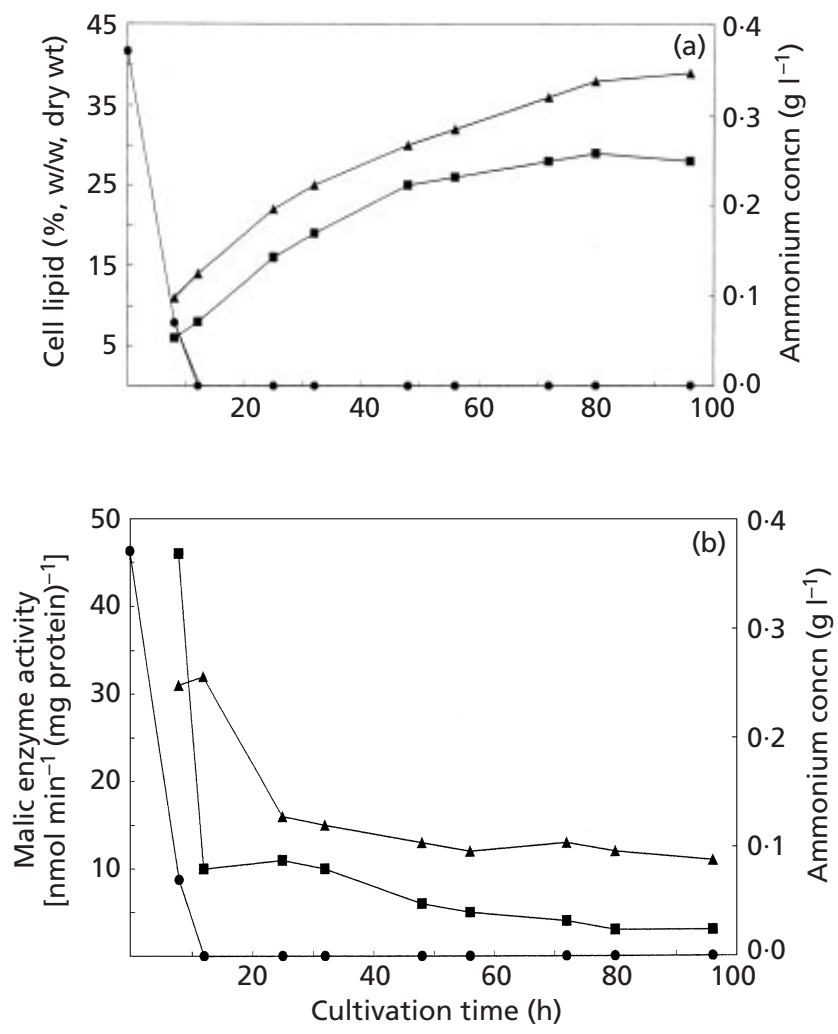

Fig. 4. (a) Effect of carbon source on the amount of cell lipid accumulated by $M$. circinelloides. $M$. circinelloides was cultivated in a $5 \mathrm{I}$ fermenter in a high $\mathrm{C}: \mathrm{N}$ medium with either glucose or acetate as the sole carbon source. 0 , Culture $\mathrm{NH}_{4}^{+}$ concentration; $\boldsymbol{\square}$, cell lipid in glucose-grown cells; $\boldsymbol{\Delta}$, cell lipid in acetate-grown cells. (b) Effect of carbon source on the total malic enzyme activity in $M$. circinelloides. $M$. circinelloides was cultivated in a $5 \mathrm{I}$ fermenter in a high $\mathrm{C}: \mathrm{N}$ medium with either glucose or acetate as the sole carbon source. - , Culture $\mathrm{NH}_{4}^{+}$ concentration; $\mathbf{\square}$, malic enzyme activity in glucose-grown cells; $\boldsymbol{\Lambda}$, malic enzyme activity in acetate-grown cells.

higher ( $>20 \%, \mathrm{w} / \mathrm{w}$, cell dry wt) and isoform IV was now the predominant isoform of malic enzyme.

These results suggest that the decrease in malic enzyme activity detected in batch culture after $\mathrm{N}$-exhaustion and coinciding with lipid accumulation (Fig. 4; Wynn et al., 1999) may not be a result of the degradation of a single form of malic enzyme as was previously thought to be the case. Instead, it appears likely that this change in activity was the result of a change in the isoform of malic enzyme present in the cells. In response to a decrease in the growth rate, initiated by a limitation in the supply of nitrogen, one form of malic enzyme (isoform III) disappeared and another (isoform IV) appeared. It is not yet clear if isoform IV appears as a result of de novo synthesis or by conversion/modification of isoform III; however, isoform IV is clearly the most important isoform of malic enzyme under conditions of lipid accumulation by M. circinelloides. Isoform IV, however, appears not to be inherently stable as within $24-30 \mathrm{~h}$ of its formation all activity of malic enzyme had ceased and coincident with this so does lipid synthesis (Wynn et al., 1999).

\section{Growth of $M$. circinelloides under anaerobic conditions}

Malic enzyme has been suggested to play a role in anaerobic growth of Saccharomyces cerevisiae (Boles et al., 1998). Furthermore, it has previously been observed that growth of $M$. circinelloides in vortex-aerated 11 bottles (during which $\mathrm{O}_{2}$-transfer to the cells is limited) leads to increased activity of malic enzyme (J. P. Wynn, unpublished work) and the occurrence of multiple isoforms of malic enzyme (this study). Therefore the effect of anaerobic growth on (i) lipid accumulation by M. circinelloides, (ii) the activity of malic enzyme and (iii) the isoforms present was studied.

When M. circinelloides was grown under anaerobic conditions, malic enzyme activity was higher than in aerobically cultivated biomass (by three- to sixfold) and between three and five isoforms were present in the biomass (see Table 1). The only isoform that was consistently absent from biomass grown under anaerobic conditions was isoform IV. Under anaerobic conditions the cell lipid content was very low $(<2 \%$, $\mathrm{w} / \mathrm{w}$, dry wt) and the amount of unsaturated fatty acids in the cell lipid was severely restricted (see Table 2).

During anaerobic growth, the flux of carbon from pyruvate would be into ethanol rather than into citrate as the complete citric acid cycle will not be operating under these conditions. However, as pyruvate dehydrogenase is a mitochondrial enzyme in eukaryotic cells, some carbon must flow via citrate (the form in which mitochondrial acetyl units are exported to the cytosol) in order to generate enough cytosolic acetyl-CoA for anabolic processes, including de novo fatty acid biosynthesis for cell membrane formation. The $2 \%(\mathrm{w} / \mathrm{w})$ dry weight lipid in anaerobically grown cells probably reflects the minimum content of lipid for a viable cell (Wynn et al., 1997). The fatty acids in anaerobically grown cells will be primarily in the form of membrane phospholipid and little 'metabolically inactive' storage triacylglycerol would be accumulated.

In response to $\mathrm{O}_{2}$-limited growth conditions, $M$. circinelloides displayed changes in the fatty acid profiles that compensate for a lack of fatty acid desaturase activity, which is an $\mathrm{O}_{2}$-dependent process. While the content of the unsaturated fatty acids in general, and the polyunsaturated fatty acids in particular, decreased, the amount of short-chain fatty acids (12:0 and 14:0) increased. A change to shorter chain fatty acids, with lower melting points, would maintain the fluidity of cell membranes under conditions where efficient desaturation could not occur. That some fatty acid desaturation occurred demonstrated that the conditions in the cultures were not completely anaerobic and that sufficient $\mathrm{O}_{2}$ was entering the system (probably dissolved in the incoming medium which was not de-oxygenated) to maintain a basal level of fatty acid desaturation. 

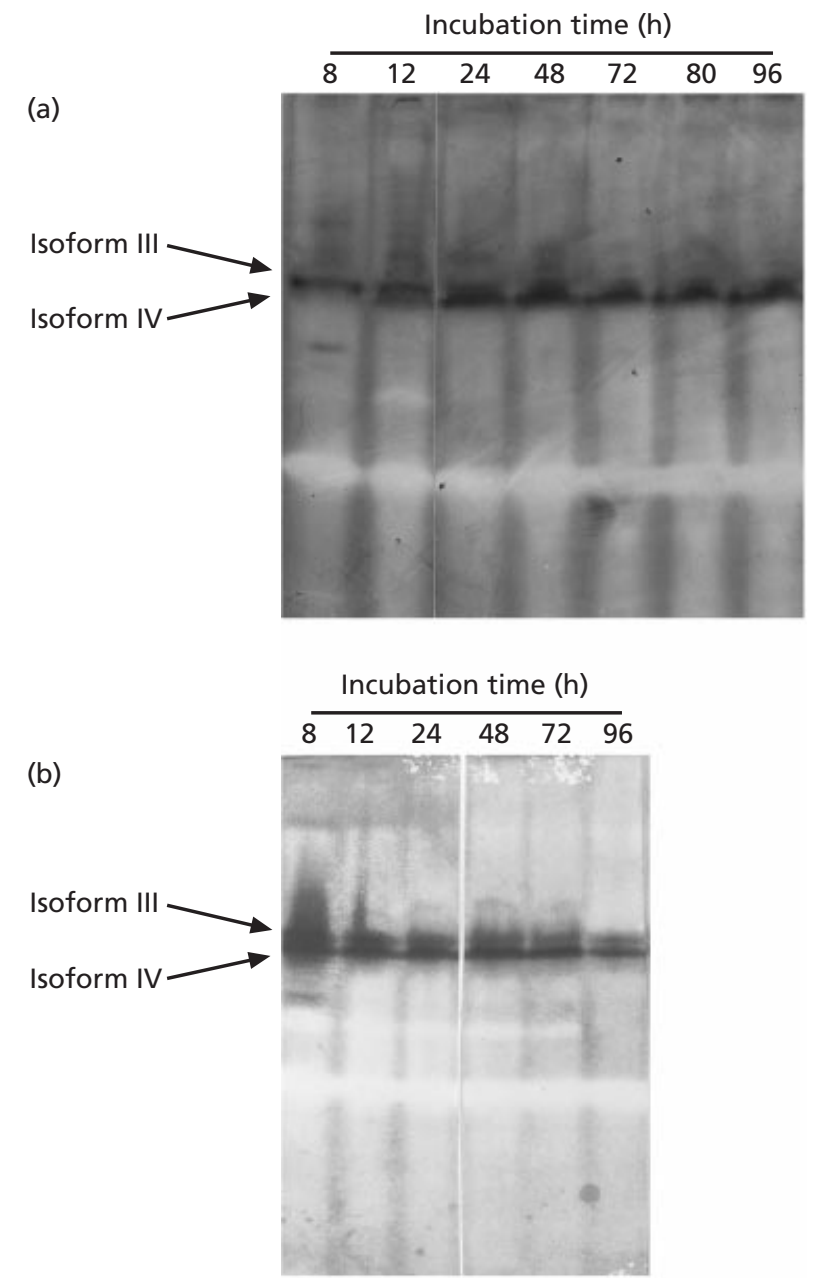

Fig. 5. Effect of carbon source on the isoforms of malic enzyme (EC 1.1.1.40) in M. circinelloides during batch fermentation. $M$. circinelloides was cultivated in (a) batch culture with glucose as the sole carbon source and (b) fed-batch culture with acetate as the sole carbon source. Cell extracts were prepared at intervals and stained for malic enzyme activity after native PAGE.
When M. circinelloides was cultivated in an atmosphere rich in $\mathrm{CO}_{2}$, the activity of malic enzyme was particularly high and isoform VI appeared (Table 1). This correlated with the detection of a pyruvate- and $\mathrm{HCO}_{3}^{-}$dependent oxidation of NADPH in crude extracts which was assumed to be the result of a pyruvate carboxylating activity of isoform VI. It therefore appears that isoform VI is peculiar in that it alone can catalyse a 'reverse' (i.e. carboxylation) malic enzyme reaction. The in vivo importance of this minor carboxylating activity is unclear (especially as it constituted only $5 \%$ of the decarboxylating activity of malic enzyme in crude extracts) but it does suggest that isoform VI is significantly different from the others found in $M$. circinelloides.

\section{Effect of growth of $\boldsymbol{M}$. circinelloides on acetate}

The effect of acetate on the growth, lipid production and malic enzyme activity of M. circinelloides is of particular interest as previous work with Aspergillus nidulans (McCullough \& Roberts, 1974) demonstrated that acetate as a sole carbon source led to an increase in the activity of malic enzyme. Furthermore, growth on acetate has been found to increase the maximum extent of lipid accumulation by M. circinelloides (Du Preez et al., 1997).

When M. circinelloides was grown in a $\mathrm{pH}$-auxostat (fed-batch) culture with acetate supplied continuously as the carbon source (viz. Du Preez et al., 1997), the cell lipid content was $35 \%$ greater than in glucose-grown cultures (Fig. 4a). The malic enzyme activity in acetategrown cultures at or before N-limitation (Fig. 4b) was lower than that in glucose-grown cells [30-35 nmol $\min ^{-1}$ (mg protein $)^{-1}$ compared to $>45 \mathrm{nmol} \mathrm{min}{ }^{-1}$ $(\mathrm{mg} \text { protein })^{-1}$. However, after $\mathrm{N}$-exhaustion the activity of malic enzyme in acetate-grown cells remained higher $\left[\sim 15 \mathrm{nmol} \mathrm{min}^{-1}\left(\mathrm{mg}\right.\right.$ protein $\left.\left.{ }^{-1}\right)\right]$ than in glucose-grown cells [between 3 and $10 \mathrm{nmol} \mathrm{min}{ }^{-1}$ (mg protein $\left.)^{-1}\right]$. The difference in the isoform profiles of the

Table 3. Purification of malic enzyme isoforms III and IV from M. circinelloides

Steps: 1, ultracentrifugation; $2,\left(\mathrm{NH}_{4}\right)_{2} \mathrm{SO}_{4}$ precipitation (50-60\% saturation); 3, Sephacryl S-200-HR gel filtration; 4, DEAE anionexchange chromatography; 5, Sephacryl S-200-HR gel filtration; 6, Mimetic Green affinity chromatography.

\begin{tabular}{|c|c|c|c|c|c|c|}
\hline \multirow[t]{2}{*}{ Step } & \multicolumn{3}{|c|}{ Isoform III } & \multicolumn{3}{|c|}{ Isoform IV } \\
\hline & 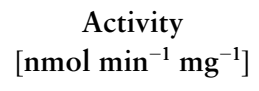 & $\begin{array}{l}\text { Purification } \\
\text { (-fold) }\end{array}$ & $\begin{array}{c}\text { Recovery } \\
(\%)\end{array}$ & 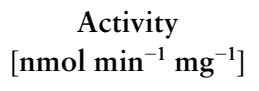 & $\begin{array}{l}\text { Purification } \\
\text { (-fold) }\end{array}$ & $\begin{array}{c}\text { Recovery } \\
(\%)\end{array}$ \\
\hline Crude extract & 17 & 1 & 100 & 5 & 1 & 100 \\
\hline 1 & 26 & $1 \cdot 5$ & 95 & 7 & $1 \cdot 5$ & 95 \\
\hline 2 & 68 & 4 & 73 & 22 & $4 \cdot 5$ & 66 \\
\hline 3 & 410 & 24 & 62 & 110 & 23 & 47 \\
\hline 4 & 1641 & 96 & 30 & 326 & 68 & 22 \\
\hline 5 & 1744 & 102 & 12 & 398 & 83 & 8 \\
\hline 6 & 6703 & 392 & $1 \cdot 3$ & 1387 & 289 & $1 \cdot 1$ \\
\hline
\end{tabular}




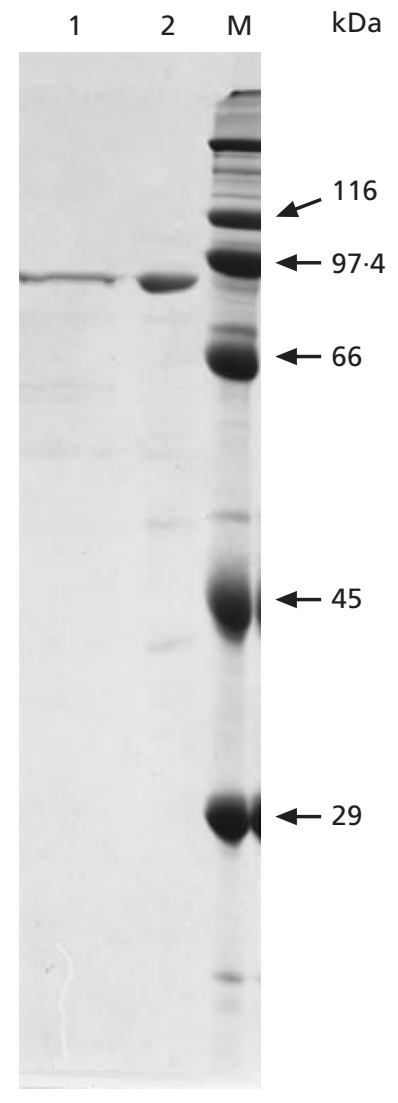

Fig. 6. SDS-PAGE of purified malic enzyme (EC 1.1.1.40) isoforms III and IV from $M$. circinelloides. Biomass was cultivated in aerated fermenters and harvested prior to $\mathrm{N}$-exhaustion for the purification of isoform III and after $\mathrm{N}$-exhaustion for the purification of isoform IV. Lanes: 1, isoform $\mathrm{IV} ; 2$, isoform III; M, molecular mass markers. cells grown on the different carbon sources was probably more significant than the actual specific activity recorded for malic enzyme, which does not distinguish between the isoforms (Fig. 5). Cells grown on glucose contained only isoform III prior to N-exhaustion. After Nexhaustion and during lipid accumulation, isoform III became less quantitatively important and isoform IV appeared, and became the predominant isoform. In contrast, cells grown on acetate possessed both isoforms III and IV even prior to $\mathrm{N}$-exhaustion, although again isoform III disappeared during the lipid accumulation idiophase.

These data again link isoform IV of malic enzyme with lipid accumulation in M. circinelloides and appear, for the first time, to give a biochemical explanation for the ability of acetate to induce increased lipid accumulation in M. circinelloides, which is caused via its induction of the formation of isoform IV of malic enzyme.

\section{Purification of isoforms III and IV from M. circinelloides}

Both isoforms III and IV were purified to homogeneity from aerobic cultures of $M$. circinelloides. The same purification protocol was used for each isoform but the biomass used for the purification was harvested at different times and from cultures cultivated on different carbon sources (Table 3). Isoform III was purified from glucose-grown biomass, harvested prior to N-exhaustion, and isoform IV was purified from acetate-grown biomass, harvested after N-exhaustion. Therefore, isoform III was isolated from biomass devoid of isoform IV and isoform IV was isolated from biomass devoid of isoform III. Although the purified isoforms were clearly

Table 4. N-terminal amino acid sequence of $M$. circinelloides malic enzyme isoforms III and IV compared with those of other organisms

\begin{tabular}{|c|c|c|c|c|c|c|c|c|c|c|c|c|c|c|c|c|c|c|c|c|}
\hline \multirow[t]{2}{*}{ Source } & \multicolumn{20}{|c|}{ Amino acid at position: } \\
\hline & 1 & 2 & 3 & 4 & 5 & 6 & 7 & 8 & 9 & 10 & 11 & 12 & 13 & 14 & 15 & 16 & 17 & 18 & 19 & 20 \\
\hline M. circinelloides isoform III & $\mathrm{V}$ & $\mathrm{V}$ & $\mathrm{A}$ & $\mathrm{T}$ & $\mathrm{N}$ & $\mathrm{L}$ & G & $\mathrm{F}$ & $\mathrm{P}$ & $\mathrm{Y}$ & $\mathrm{V}$ & G & $\mathrm{A}$ & $\mathrm{K}$ & $\mathrm{R}$ & $\mathrm{E}$ & $\mathrm{L}$ & $\mathrm{K}$ & $\mathrm{K}$ & S \\
\hline M. circinelloides isoform IV & $\mathrm{V}$ & $\mathrm{V}$ & A & $\mathrm{T}$ & $\mathrm{N}$ & $\mathrm{L}$ & G & $\mathrm{F}$ & $\mathrm{P}$ & $\mathrm{Y}$ & $\mathrm{V}$ & G & A & $\mathrm{K}$ & $\mathrm{R}$ & $\mathrm{E}$ & $\mathrm{L}$ & $\mathrm{K}$ & $\mathrm{K}$ & S \\
\hline Human (mitochondrial) & M & G & A & A & $\mathrm{L}$ & G & $\mathrm{T}$ & G & $\mathrm{T}$ & $\mathrm{R}$ & $\mathrm{L}$ & $\mathrm{A}$ & $\mathrm{P}$ & W & $\mathrm{P}$ & G & $\mathrm{R}$ & A & $\mathrm{C}$ & G \\
\hline Human & M & $\mathrm{E}$ & $\mathrm{P}$ & $\mathrm{E}$ & A & $\mathrm{P}$ & $\mathrm{R}$ & $\mathrm{R}$ & $\mathrm{R}$ & $\mathrm{H}$ & $\mathrm{T}$ & $\mathrm{H}$ & Q & $\mathrm{R}$ & G & $\mathrm{Y}$ & $\mathrm{L}$ & $\mathrm{L}$ & $\mathrm{T}$ & $\mathrm{R}$ \\
\hline Rat & $\mathrm{M}$ & $\mathrm{D}$ & $\mathrm{P}$ & $\mathrm{R}$ & A & $\mathrm{P}$ & $\mathrm{R}$ & $\mathrm{R}$ & $\mathrm{R}$ & $\mathrm{H}$ & $\mathrm{T}$ & $\mathrm{H}$ & Q & $\mathrm{R}$ & G & $\mathrm{Y}$ & $\mathrm{L}$ & $\mathrm{L}$ & $\mathrm{T}$ & $\mathrm{R}$ \\
\hline Pig & G & $\mathrm{Y}$ & G & $\mathrm{L}$ & $\mathrm{T}$ & $\mathrm{R}$ & I & $\mathrm{P}$ & $\mathrm{H}$ & $\mathrm{L}$ & $\mathrm{N}$ & $\mathrm{K}$ & $\mathrm{D}$ & $\mathrm{L}$ & $\mathrm{A}$ & $\mathrm{F}$ & $\mathrm{T}$ & $\mathrm{L}$ & $\mathrm{E}$ & $\mathrm{E}$ \\
\hline Mouse & M & $\mathrm{E}$ & $\mathrm{P}$ & $\mathrm{R}$ & A & $\mathrm{P}$ & $\mathrm{R}$ & $\mathrm{R}$ & $\mathrm{R}$ & $\mathrm{H}$ & $\mathrm{T}$ & $\mathrm{H}$ & $\mathrm{Q}$ & $\mathrm{R}$ & G & $\mathrm{Y}$ & $\mathrm{L}$ & $\mathrm{L}$ & $\mathrm{T}$ & $\mathrm{R}$ \\
\hline Pigeon & M & K & K & G & Y & $\mathrm{E}$ & $\mathrm{V}$ & $\mathrm{L}$ & $\mathrm{R}$ & $\mathrm{D}$ & $\mathrm{P}$ & $\mathrm{H}$ & $\mathrm{L}$ & $\mathrm{N}$ & $\mathrm{K}$ & G & M & A & $\mathrm{F}$ & $\mathrm{T}$ \\
\hline Duck & M & K & $\mathrm{R}$ & G & Y & $\mathrm{E}$ & $\mathrm{V}$ & $\mathrm{L}$ & $\mathrm{R}$ & $\mathrm{D}$ & $\mathrm{P}$ & $\mathrm{H}$ & $\mathrm{L}$ & $\mathrm{N}$ & K & G & M & A & $\mathrm{F}$ & $\mathrm{T}$ \\
\hline Rice & $\mathrm{M}$ & $\mathrm{L}$ & $\mathrm{S}$ & A & $\mathrm{R}$ & A & A & A & $\mathrm{T}$ & $\mathrm{A}$ & $\mathrm{A}$ & $\mathrm{A}$ & A & A & A & $S$ & $\mathrm{P}$ & $\mathrm{L}$ & W & $\mathrm{K}$ \\
\hline Maize & $\mathrm{M}$ & $\mathrm{L}$ & $\mathrm{S}$ & $\mathrm{T}$ & $\mathrm{R}$ & $\mathrm{T}$ & A & A & $\mathrm{V}$ & $\mathrm{A}$ & $\mathrm{A}$ & S & A & $S$ & $\mathrm{P}$ & A & S & $\mathrm{P}$ & W & $\mathrm{K}$ \\
\hline Common ice plant & $\mathrm{M}$ & G & G & $S$ & $\mathrm{~N}$ & A & $\mathrm{L}$ & $\mathrm{N}$ & $\mathrm{E}$ & M & $\mathrm{T}$ & $\mathrm{N}$ & G & $S$ & $\mathrm{D}$ & G & I & $\mathrm{T}$ & G & G \\
\hline Weatern poplar & M & $\mathrm{E}$ & S & $\mathrm{T}$ & $\mathrm{L}$ & K & $\mathrm{E}$ & M & $\mathrm{R}$ & $\mathrm{D}$ & G & $\mathrm{A}$ & $S$ & $\mathrm{~V}$ & $\mathrm{~L}$ & $\mathrm{D}$ & M & $\mathrm{D}$ & $\mathrm{P}$ & K \\
\hline Grape & M & $\mathrm{E}$ & $S$ & $\mathrm{~T}$ & $\mathrm{~L}$ & K & $\mathrm{D}$ & I & $\mathrm{R}$ & $\mathrm{D}$ & G & $\mathrm{A}$ & $S$ & $\mathrm{~V}$ & $\mathrm{~L}$ & $\mathrm{D}$ & $\mathrm{L}$ & $\mathrm{D}$ & $\mathrm{P}$ & K \\
\hline Kidney bean & $\mathrm{M}$ & $\mathrm{S}$ & $\mathrm{S}$ & I & $S$ & $\mathrm{~L}$ & $\mathrm{~K}$ & $\mathrm{E}$ & $\mathrm{N}$ & G & G & $\mathrm{E}$ & $\mathrm{V}$ & $S$ & $\mathrm{~V}$ & K & K & $\mathrm{D}$ & $\mathrm{Y}$ & $\mathrm{S}$ \\
\hline Tomato & I & $\mathrm{R}$ & $\mathrm{H}$ & $\mathrm{E}$ & $S$ & $\mathrm{~T}$ & $\mathrm{~V}$ & $\mathrm{~T}$ & G & G & $\mathrm{V}$ & $\mathrm{Q}$ & $\mathrm{D}$ & $\mathrm{V}$ & Y & G & $\mathrm{E}$ & $\mathrm{D}$ & $\mathrm{S}$ & A \\
\hline Roundworm & $\mathrm{P}$ & $\mathrm{R}$ & $\mathrm{V}$ & $\mathrm{R}$ & $S$ & $\mathrm{~F}$ & I & A & $\mathrm{H}$ & $\mathrm{Q}$ & $\mathrm{S}$ & G & I & $\mathrm{T}$ & $\mathrm{S}$ & $\mathrm{V}$ & I & $\mathrm{R}$ & $\mathrm{R}$ & $\mathrm{S}$ \\
\hline
\end{tabular}


separated by native PAGE (Fig. 1) after purification, they appeared identical when run on SDS-PAGE (Fig. 6). Therefore, the two isoforms appear to be composed of subunits of the same molecular size. The difference in migration on the native gels, therefore, reflects either a difference in the number of subunits possessed by isoforms III and IV or a modification of a subunit of similar size. This could be perhaps by the possession or absence of a charged moiety such as a phosphate.

The first $20 \mathrm{~N}$-terminal amino acids of the purified isoform III and IV proteins were determined by sequencing commercially and found to be identical (Table 4). The fungal proteins were distinct from both animal and plant malic enzymes (Table 4). Although some similarity exists between malic enzyme from closely related sources, no other two proteins exhibited identical N-terminal amino acid sequences like isoforms III and IV. Furthermore, the two different isoforms from humans exhibited a wide degree of divergence. It is our assertion that the identical amino acid sequence at the $\mathrm{N}$-termini of isoforms III and IV suggests that these proteins are encoded by a single gene.

It requires mentioning that the amino acid alignments presented in Table 4 in many cases include amino acid sequences deduced from the gene sequence (i.e. they retain the terminal methionine) rather than from purified proteins per se. Our sequences represent the sequences of the mature proteins which may therefore have undergone post-translational modification (the removal of a signal peptide, etc.). It is possible, therefore, that we are not comparing equivalent stretches of the translated protein; however, the basis of our argument, that the sequences from malic enzyme isoforms III and IV display a unique level of similarity and are likely to be the product of a single gene, is unaffected.

Due to the similarity of the subunits of isoform III and IV in terms of their molecular mass and $\mathrm{N}$-terminal amino acid sequence and the way in which isoform III disappears at the time that isoform IV appears, it is our hypothesis that isoform IV is produced from isoform III by a process of post-translational modification. The most likely processes to be involved are either partial proteolytic cleavage or phosphorylation or dephosphorylation. However, attempts to clarify which of these processes is the one operating in vivo have so far been inconclusive.

\section{ACKNOWLEDGEMENTS}

Throughout this work J.P.W. was supported by a BBSRC Link grant in collaboration with Avecia, Roche and Newtec Laboratories. Expert technical assistance was provided by Mrs Maureen Ewing. Y.S. and Y.L. were supported by scholarships from the University of Hull.

\section{REFERENCES}

Boles, E., Jong-Gubbels, P. \& Pronk, J. T. (1998). Identification and characterization of MAE1, the Saccharomyces cerevisiae struc- tural gene encoding mitochondrial malic enzyme. J Bacteriol 180, 2875-2882.

Bradford, M. M. (1976). A rapid and sensitive method for the quantitation of microgram quantities of protein utilizing the principle of protein-dye binding. Anal Biochem 72, 248-254.

Chaney, A. L. \& Marbach, E. P. (1962). Modified reagents for the determination of ammonium and urea. Clin Chem 8, 130-132.

Chang, G. G., Wang, J. K., Huang, T. M., Lee, H. J., Chou, W. Y. \& Meng, C. L. (1991). Purification and characterization of the cytosolic $\mathrm{NADP}^{+}$-dependent malic enzyme from human cancer cell line. Eur J Biochem 202, 681-688.

Du Preez, J. C., Immelman, M., Kock, J. L. F. \& Killian, S. G. (1997). The effect of acetic acid concentration on the growth and production of gamma-linolenic acid by Mucor circinelloides CBS 203.28 in fed-batch culture. World J Microbiol Biotechnol 13, 81-87.

Evans, C. T. \& Ratledge, C. (1985). Possible regulatory roles of ATP: citrate lyase, malic enzyme and AMP deaminase in lipid Rhodosporidium toruloides CBS 14. Can J Microbiol 31, 1000-1005.

Folch, J., Lees, M. \& Sloane-Stanley, G. H. (1957). A simple method for the isolation of total lipides from animal tissues. $\mathrm{J} \mathrm{Biol}$ Chem 226, 497-509.

Frenkel, R. (1975). Regulation and physiological functions of malic enzymes. Curr Top Cell Regul 9, 157-181.

Hames, B. D. (1985). An introduction to polyacrylamide gel electrophoresis of proteins. In Gel Electrophoresis of Proteins: a Practical Approach, pp. 1-91. Edited by B. D. Hames \& D. Rickwood. Oxford: IRL Press.

Hodnett, D. W., Fantozzi, D. A., Thurmond, D. C., Klautky, S. A., MacPhee, K. G., Estrem, S. T., Xu, G. \& Goodridge, A. G. (1996). The chicken malic enzyme gene: structural organization and identification of triiodothyronine response elements in the $5^{\prime}$ flanking DNA. Arch Biochem Biophys 334, 309-324.

Hsu, R. Y. \& Lardy, H. A. (1969). Malic enzyme. Methods Enzymol 13, 230-235.

Kendrick, A. \& Ratledge, C. (1992). Lipid formation in the oleaginous mould Entomophthora exitalis grown in continuous culture: effects of growth rate, temperature and dissolved oxygen tension on polyunsaturated fatty acids. Appl Microbiol Biotechnol 37, 18-22.

McCullough, W. \& Roberts, C. F. (1974). The role of malic enzyme in Aspergillus nidulans. FEBS Lett 41, 238-242.

Ochoa, S., Mehler, A. H. \& Kornberg, A. (1947). Reversible oxidative decarboxylation of malic acid. J Biol Chem 167, 871-872.

Ratledge, C. \& Wynn, J.P. (2000). Understanding microbial obesity. SIM News 50, 181-185.

Savitha, J., Wynn, J. P. \& Ratledge, C. (1997). Malic enzyme: its purification and characterization from Mucor circinelloides and occurrence in other oleaginous fungi. World J Microbiol Biotechnol 13, 7-9.

Viljoen, M., Subden, R. E., Krizus, A. \& Van Vuuren, H. J. J. (1994). Molecular analysis of the malic enzyme gene (mae2) of Schizosaccharomyces pombe. Yeast 10, 613-624.

Walter, M. H., Grima-Pettenati, J. \& Feuillet, C. (1994). Characterization of the bean (Phaseolus vulgaris L.) malic enzyme gene. Eur J Biochem 224, 999-1009.

Wynn, J. P. \& Ratledge, C. (1997). Malic enzyme is a major source of NADPH for lipid accumulation by Aspergillus nidulans. Microbiology 143, 253-257. 
Wynn, J. P. \& Ratledge, C. (2000). Evidence that the rate-limiting step for the biosynthesis of arachidonic acid in Mortierella alpina is at the level of the 18:3 to 20:3 elongase. Microbiology 146, 2325-2331.

Wynn, J. P., Kendrick, A. \& Ratledge, C. (1997). Sesamol as an inhibitor of growth and lipid metabolism in Mucor circinelloides via its action on malic enzyme. Lipids 32, 605-610.

Wynn, J. P., Hamid, A. A. \& Ratledge, C. (1999). The role of malic enzyme in the regulation of lipid accumulation in filamentous fungi. Microbiology 145, 1911-1917.

Zink, M. W. (1972). Regulation of the two malic enzymes in Neurospora crassa. Can J Microbiol 18, 611-617.

Received 8 December 2000; revised 14 February 2001; accepted 22 February 2001. 